\title{
A preliminary assessment of carbon storage suitability in deep underground geological formations of New Brunswick, Canada
}

\author{
DAVE KeIGHLEY* AND CRYSTAL MAHER
}

Department of Earth Sciences, University of New Brunswick, Fredericton, New Brunswick E3B 5A3, Canada

*Corresponding author <keig@unb.ca $>$

Date received: 10 November 2014 Date accepted: 30 June 2015

\begin{abstract}
An assessment of the surface and subsurface geology in New Brunswick has identified several regions, close to Large Final Emitters (industrial sites releasing carbon dioxide, $\mathrm{CO}_{2}$, into the atmosphere), underlain by large volumes of various sedimentary rocks that could act as either the reservoir or seal in a carbon storage operation. There is a lack of subsurface data with which to make an assessment for the New Brunswick Platform, the Gulf of St. Lawrence, and Northumberland Strait. In the Moncton Basin, the McCully Gas Field is hosted in tight gas sands where it would be difficult to pump down $\mathrm{CO}_{2}$ at an economical rate. The Stoney Creek Oil and Gas Field south of Moncton is not at sufficient depth for $\mathrm{CO}_{2}$ to be in a supercritical state, necessary for compressed storage. Saline reservoirs could underlie suitably large areas around these fields, but again there is limited information on the quality of the potential reservoir rock. In the Bay of Fundy, south of Saint John, one borehole indicates a prospective location that includes a saline reservoir with suitable thickness and wireline-calculated porosity and permeability, a seal with suitable thickness, and limited faulting to potentially compartmentalize the reservoir or, conversely, compromise the continuity of the seal. The major uncertainty is trap volume, which is particularly difficult to assess based on the borehole being the only data point within a $50 \mathrm{~km}$ radius. This is also an environmentally sensitive offshore area. Until data deficiencies are addressed, no locations can be recommended for carbon storage.
\end{abstract}

\section{RÉSUMÉ}

Une évaluation de la géologie de surface et de subsurface au Nouveau-Brunswick a permis le repérage de plusieurs régions proches de grands émetteurs finals (sites industriels rejetant du dioxyde de carbone $-\mathrm{CO}_{2}-$ dans l'atmosphère) reposant sur des volumes importants de diverses roches sédimentaires qui pourraient agir comme réservoirs ou matériau de scellement pour le stockage de carbone. On dispose de données de subsurface insuffisantes pour effectuer une évaluation dans le cas de la plate-forme du Nouveau-Brunswick, du golfe du Saint-Laurent et du détroit de Northumberland. Dans le bassin de Moncton, le champ gazier McCully est inclus dans des sables à gaz compacts où il serait difficile de stocker du $\mathrm{CO}_{2}$ par pompage à un coût économique. Le champ pétrolier et gazier de Stoney Creek au sud de Moncton n'a pas une profondeur suffisante pour que le $\mathrm{CO}_{2}$ atteigne létat supercritique essentiel au stockage sous compression. Des réservoirs salins pourraient reposer sous des secteurs suffisamment vastes près de ces champs, mais encore une fois, on dispose de renseignements limités sur la qualité des roches-réservoirs éventuelles. Dans la baie de Fundy, au sud de Saint John, un trou de forage signale un emplacement possible comprenant un réservoir salin d'une épaisseur et d'une porosité et perméabilité, calculées au moyen d'un essai au câble, qui conviennent, un matériau de scellement d'une épaisseur adéquate et une déformation par des failles limitée pour une éventuelle compartimentalisation du réservoir ou, à l’opposé, une absence de continuité du matériau de scellement. Le principal aspect incertain est le volume de la zone de piégeage, qui est particulièrement difficile à évaluer du fait que le trou de forage constitue la seule source de données dans un rayon de 50 kilomètres. Il s'agit en outre d'un secteur extracôtier écosensible. Aucun emplacement ne pourra être recommandé pour le stockage de carbone jusquà ce qu'on obtienne les données qui manquent.

[Traduit par la redaction] 


\section{INTRODUCTION}

Increasing amounts of carbon dioxide $\left(\mathrm{CO}_{2}\right)$ in the global atmosphere were first identified by Keeling (1960), and in the subsequent years annual peak concentrations have steadily risen from $\sim 315 \mathrm{ppm}$ to over $400 \mathrm{ppm}$ in May 2013 (National Oceanic and Atmospheric Administration 2013). Although these gases are produced naturally, much of the increase has been attributed directly and indirectly to human activity. Carbon-based natural resources, such as coal, oil, and natural gas (methane), increasingly have been used over the last century as a source of energy for transport, heating, and electricity generation. Such use requires that they be burnt, resulting in, amongst other waste products, $\mathrm{CO}_{2}$. Total annual Canadian emissions (year 2012 data) were $699 \mathrm{Mt} \mathrm{CO}_{2}$ equivalents, of which $\mathrm{CO}_{2}$ emissions contributed 79\%; New Brunswick contributed just under $20 \mathrm{Mt} \mathrm{CO}_{2}$ equivalent (Environment Canada 2014).

Increased atmospheric $\mathrm{CO}_{2}$ can lead to changes in animal and plant metabolism (e.g., Taub 2010). More of the gas subsequently being absorbed into oceans and lakes can lead to greater acidification of these water bodies (e.g., Caldeira and Wickett 2003). Carbon dioxide is also a "greenhouse gas" because it limits the amount of heat that is radiated out from the Earth into space. Accordingly, along with other natural and anthropogenic factors, the gas is deemed to have played a potentially significant role in recent warming of temperatures in many parts of the world, i.e., "global warming" (International Panel on Climate Change 2013). The concentration of $\mathrm{CO}_{2}$ is also predicted to continue rising in the upcoming years unless there is action taken to (i) actively remove $\mathrm{CO}_{2}$ from the atmosphere (e.g., tree planting, algal farming), (ii) reduce use of carbon-based fuel, and (iii) reduce carbon emissions to the atmosphere (International Panel on Climate Change 2013).

Limiting further emissions of $\mathrm{CO}_{2}$ to the atmosphere involves the capture and separation of $\mathrm{CO}_{2}$ at the wastegas source. After successful isolation from waste emissions, the $\mathrm{CO}_{2}$ must then be converted into a different product, or stored (sequestered), the latter usually also requiring transportation of the gas from the capture point to the storage area. In general, transportation would involve the construction of pipeline to carry $\mathrm{CO}_{2}$ gas under significant pressure. For example, at over 75 bar pressure and $32^{\circ} \mathrm{C}$, $\mathrm{CO}_{2}$ acts as a supercritical fluid, whereby the vapour (gas) phase becomes as dense as the liquid phase yet flows as easily as a gas, diffuses like a gas, dissolves other material like a liquid, and has no surface tension (Span and Wagner 1996). Transport issues might include routing and land procurement, burial, insulation, and metal corrosion (fortunately, $\mathrm{CO}_{2}$ is not combustible). Storage may involve $\mathrm{CO}_{2}$ being dissolved in aqueous solution or retained either in its gaseous state or as a supercritical fluid. Alternatively, it might be converted into organic carbon or an inorganic (carbonate) compound. To be successful, such methods of limiting emissions must be effective and cost-competitive, provide stable, long-term monitored and verified conversion/storage, be environmentally friendly, and have wide public acceptance.

In 2005, under a G8 Workshop Series (Gleneagles) recommendation, Canada was committed to mapping prospective carbon storage regions in its territory, and calculating storage capacity estimates. A Technical Committee for the "Approach and Data Needs for the Production of the National Atlas of $\mathrm{CO}_{2}$ Geological Storage Potential and Capacity in Canada" (Bachu, unpublished 2010) was established. Based on this committee's work, this contribution represents a first stage regional assessment of potential storage in underground geologic formations in New Brunswick. The criteria assessed relate to $\mathrm{CO}_{2}$ storage, but they are similar criteria to what would have to be reviewed for storage of other fluid wastes.

\section{TYPES OF UNDERGROUND STORAGE}

Sedimentary rocks at depth have the potential to trap and store waste-captured $\mathrm{CO}_{2}$, or other fluids. Physical trapping takes place in either microfractures or spaces (pores) between mineral grains. Typically, pore volume (porosity) accounts for less than $20 \%$ of the total rock volume. The $\mathrm{CO}_{2}$ would be pumped through and stored in the pore space as a free gas, or more efficiently as a supercritical fluid. Some will also be stored by capillary forces (Andrew et al. 2013). In regions with normal thermal gradients and hydrostatic pressure gradients in the subsurface, at depths of over $1 \mathrm{~km} \mathrm{CO}$ is in its supercritical phase and thus denser so more can be stored per unit volume of rock. Some $\mathrm{CO}_{2}$ also will dissolve to form aqueous complexes in the subsurface fluids (chemical trapping), be adsorbed onto mineral surfaces (adsorption trapping), and react with the rock matrix to form new minerals (mineral trapping). These non-physical trapping mechanisms occur naturally only on geological time scales and so do not contribute to initial storage calculations (e.g., Mito et al. 2013). Three types of underground geologic formation are being seriously considered for carbon storage (Solomon et al. 2008) and are described below, although studies of mechanisms that may adversely impact long term storage are somewhat limited for each (e.g., references in Kaszuba et al. 2005; Verdon et al. 2011; Wilke et al. 2012). Salt caverns also have been proposed for storage but have relatively low capacity and so are more likely to play a role for temporary storage and, or, as a buffer in collector and distributor systems (Bachu et al. 2007).

\section{Petroleum (oil and natural gas) reservoirs}

Petroleum is typically found deep underground in small, connected pores or microfractures within sandstone or limestone. Such connectivity allows fluid to flow, giving the rock an inherent permeability. Carbon dioxide may similarly be pumped through and stored in the pore space 
(physical trapping). Petroleum remains in the subsurface permeable rock (reservoir) because the composition and geometry of the overlying rock have provided a long-term barrier (seal) to the upward flow of the petroleum, thus trapping the buoyant fluid at depth. The seal rock has either fractures or pores that are too small and disconnected for fluids to flow through (e.g., shale), or it lacks such spaces altogether (e.g., rock-salt). The effectiveness of a seal is dependent on the fluid present. Fractures that might be too small for large molecules of oil to pass through may be large enough to allow seepage of natural gas (methane) molecules. Carbon dioxide has a kinetic diameter even smaller than methane and so a rock might be impermeable to methane, but permeable to $\mathrm{CO}_{2}$.

Injecting $\mathrm{CO}_{2}$ under pressure can increase pressures in a petroleum reservoir, allowing more petroleum to be extracted. Some $\mathrm{CO}_{2}$ can also be absorbed into the oil (Perez et al. 2006), essentially making it less viscous and improving its flow to the well-bore (Emberley et al. 2005). The extra oil produced, however, also brings the $\mathrm{CO}_{2}$ back to the surface. The most widely reported trial and monitoring of such $\mathrm{CO}_{2}$ injection is at the Weyburn oil field in Saskatchewan where over $18 \mathrm{Mt}$ have already been stored under the $500 \mathrm{~km}^{2}$ test area (Wildgust et al. 2013). The cost of piping the waste $\mathrm{CO}_{2}$ from a power plant is being offset by an estimated additional 155 million barrels of oil produced at the field (Emberley et al. 2005). Note that this much oil, burnt as fuel, will itself produce over $40 \mathrm{Mt} \mathrm{CO}_{2}$. The stored $\mathrm{CO}_{2}$ eventually would be distributed between a dissolved phase in formation waters ("solubility" trapping) and, particularly if silicate mineral assemblages are present in the storage rock, precipitation of new carbonate-bearing mineral phases within the pores ("mineral" trapping) (Gunter et al. 2000).

\section{Coal-bed methane, shale, and oil-shale}

Seams of coal can contain large amounts of methane-rich gas adsorbed onto the surface of small but often regular fractures (cleats) in the coal. Injecting $\mathrm{CO}_{2}$ can cause the methane (natural gas) to be displaced with the $\mathrm{CO}_{2}$ being left behind, locked by adsorption, onto the coal (White et al. 2005). Methane is also a much cleaner-burning fuel than the coal that might otherwise be mined. Shale also commonly contains organic matter (oil shale in particular) that may similarly act as an adsorption substrate for $\mathrm{CO}_{2}$ storage. However, the networks of small fractures in these rocks are much more variable in interconnectedness and abundance than in coal seams, and the pore spaces much smaller than in sandstone. Most shale (likewise igneous and metamorphic rock) therefore has negligible permeability, which would limit the injection of $\mathrm{CO}_{2}$ at any meaningful rate. Artificial means of fracturing (fracking) in the subsurface are an increasingly common method adopted by the petroleum industry to increase permeability in oil and gas reservoirs, but would further add to costs.

\section{Saline aquifers}

Many geologic formations contain pores that are filled not with oil or gas, but instead with connate (saline/ alkaline) water. Such salty water $(>10000 \mathrm{mg} / \mathrm{L}$ total dissolved solids) is of no use for drinking or agriculture. Carbon dioxide may therefore be pumped down into these formations if they are not in hydraulic connectivity with potable groundwater aquifers. Increased pore pressures and lowered alkalinity can result, and it is unclear how this might affect the integrity of the formation and whether the dissolved phase or the supercritical phase may escape. Unlike the preceding two types of geological formation, injection into saline aquifers produces no commercial byproduct and so would be more costly to implement.

\section{METHODOLOGY}

This report addresses factors identified by the Technical Committee for the "Approach and Data Needs for the Production of the National Atlas of $\mathrm{CO}_{2}$ Geological Storage Potential and Capacity in Canada" (Bachu, unpublished 2010) that can influence carbon storage potential on a regional/provincial scale, and for which some data already exist in New Brunswick. Following the format of Bachu (2003, unpublished 2010), six general logistical criteria relating to the surface transportability and stationing of captured gases are first addressed. Subsequent assessment of basic sedimentary basin criteria then permits identification of the regions where more specific geological assessments may be compiled.

\section{GENERAL LOGISTIC CRITERIA}

\section{Proximity of potential storage sites to major $\mathrm{CO}_{2}$ emitters (LFEs)}

Large Final Emitters (LFEs) are stationary facilities emitting more than 100000 tonnes $(0.1 \mathrm{Mt})$ of $\mathrm{CO}_{2}$ /year, as reported to the Greenhouse Gas Division of Environment Canada under the mandatory GHG Emissions Reporting Program introduced by the Government of Canada in March 2004 (see Fig. 1). Facilities emitting less than 0.1 $\mathrm{Mt}$, and those whose emissions are distributed over a wide area, such as pipeline systems and major airports, are not considered as potential $\mathrm{CO}_{2}$ capture sites because the economics of capture would not be viable.

Major costs that have to be assessed when considering capture and storage include transporting the captured gas by pipeline to the underground storage site (e.g., land procurement, pipe manufacture and installation, pressure booster stations, etc.). The greater the total $\mathrm{CO}_{2}$ emissions, the more economical pipeline transport becomes per kilometre distance. The Technical Committee has suggested a ballpark figure of $500 \mathrm{~km}$ as the maximum distance 


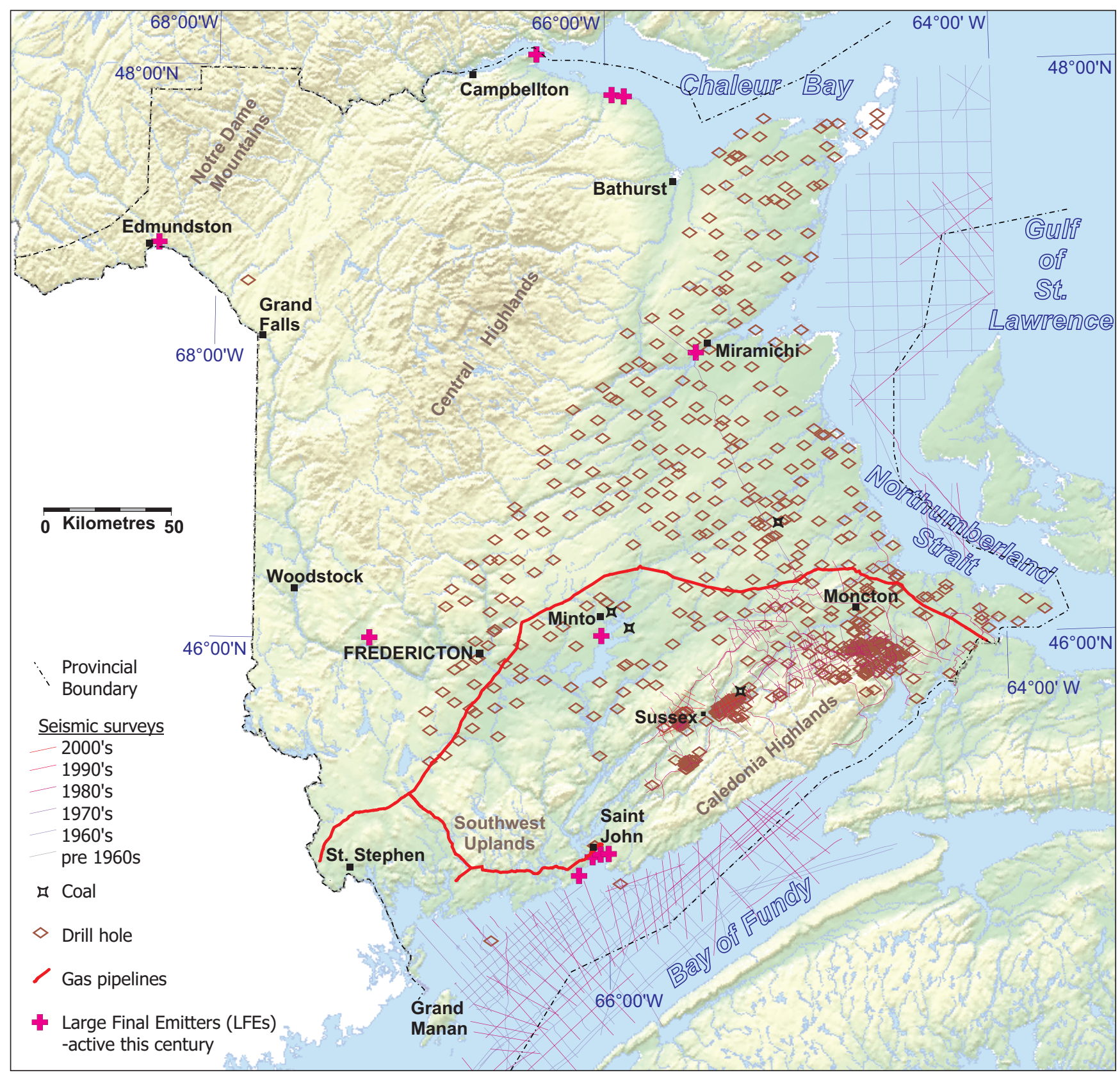

Figure 1. General topographic map of New Brunswick indicating the extent of subsurface exploration (boreholes, seismic, and coal mines) from which data can be used for more detailed studies of subsurface storage capacity.

above which $\mathrm{CO}_{2}$ transport costs become prohibitive. A concentration of major LFEs contributing to one large pipeline that was constructed across flat grasslands can extend this distance; steep mountains and valleys, or lakes, estuaries and oceans that have to be crossed would reduce this distance. Since the distance across New Brunswick in any direction never exceeds $\sim 425 \mathrm{~km}$, and the topography is nowhere severe, this logistical factor is not a detrimental issue.

\section{Climate}

Climate plays a role in the logistics equation in that extreme conditions also tend to increase transport costs. Permanently frozen ground (permafrost) of arctic and subarctic zones prohibit burial of pipe. Hot, humid conditions can promote corrosion. The relatively temperate climate across all of New Brunswick is not a barrier to carbon transport. 


\section{Accessibility (onshore, including infrastructure)}

The density of an onshore transport network (in particular, permanent roads) plays a role in the logistical equation, because pipeline routes have to be accessed for excavation and maintenance. Building and upkeep of dedicated roads for pipeline access are a significant expense that can be avoided if existing rights-of-way can be used. The expense, if necessary, is highly variable, depending on topography (steep slopes, expanses of floodplain and marsh, etc.), climate (duration of frozen ground), vegetation, and foundation (soil or bedrock). Good transport networks generally equate to workforce availability and existing industrial base, since the networks usually link larger settlements and urban areas. However, only very general guidelines have been adopted by the Technical Committee.

In New Brunswick, most of the central and northern parts of the province have only a few permanent transport routes and only small settlements. The St. Stephen - Saint John - Sussex - Moncton corridor, the north and east coasts, and Saint John River valley provide the greatest employment opportunities, existing industrial base, and transport links.

\section{Accessibility (offshore, including infrastructure)}

The expense of building and maintaining pipeline increases when the pipeline has to be submerged. The expense also increases with distance from shoreline, since technology, though expensive, can now allow near-to-shore subaqueous sites to be accessed from onshore via directional drilling of inclined and horizontal wells out beyond the coastline. Expense also increases with increasing water depth as larger, more costly, offshore drilling rigs must be used.

The offshore extent of New Brunswick's jurisdiction in the Gulf of St. Lawrence is uncertain, since there are boundary disputes with, and between neighbouring provinces. Regardless, Gulf and Straits waters remain shallow for several tens of kilometres offshore, well beyond potential boundaries. Similarly for the Bay of Fundy, most waters remain relatively shallow $(<60 \mathrm{~m})$ out beyond potential boundaries. In terms of infrastructure, no permanent offshore rigs exist in New Brunswick waters, but for both offshore areas, there are ice-free deep water ports from which offshore installations could be serviced.

\section{Regulatory status}

The pressurized transport, pumping, and storage of gases underground are regulated by government acts. For onshore New Brunswick, legislation exists in the form of the Underground Storage Act of 1978. However, it is unclear if the wording covers very long term storage and may need revision for carbon storage. Legislation for offshore beyond the coastline is further complicated by provincial disputes as to the location of provincial boundaries in the Gulf of St. Lawrence, and uncertainties as to whether joint federalprovincial governance is required in the New Brunswick portion of the Bay of Fundy.

\section{Fossil fuel exploration}

Exploration for fossil fuels typically involves the drilling of deep subsurface boreholes (beneath the zone of potable drinking water, and the depth of groundwater drinking wells), and thus potentially close to depths where carbon storage may be attempted. Also, since there is the potential to encounter combustible fluids, such drilling is highly regulated and monitored, resulting in considerable amounts of subsurface information being collected and stored (in contrast to most metallic-mineral exploration boreholes, where limited data are collected). This subsurface data typically include information regarding the rock and fluid present and often information on the physical state of the subsurface, such as temperature and pressure. Such fossil fuel exploration data provide the basis for assessment and rating of geological criteria that are discussed in the following sections. The drilling of boreholes usually follows the assessment of geophysical properties of the subsurface, such as seismic, the collection of which also provides important geological information.

In areas where there has been no coal, oil, or natural gas exploration, there is a lack of subsurface data from which a geological assessment of storage capabilities can be made. In these situations, attempting carbon storage would be highly speculative: potentially high expense without any creditable expectation of success. In places where there have been no successful petroleum finds, or where only a few oil and gas wells have been sunk, the subsurface data remain limited and, typically, localized. Where oil and gas fields have already been in production, widespread, more regularly spaced, subsurface data exist. Potentially, the economic life of wells near exhaustion might be extended by injection of $\mathrm{CO}_{2}$, thus offering an economic offset in storage costs.

Fossil fuel exploration in New Brunswick has mostly been confined to a belt running from Sussex to southeast of Moncton (Fig. 1) where a limited number of oil and gas fields are in production. More limited exploration, without success, has been attempted in the Bay of Fundy. Information from elsewhere is mostly lacking. Coal has also been mined in central New Brunswick, around Minto.

\section{GENERAL SEDIMENTARY BASIN CRITERIA}

The most basic geological criterion affecting the potential for carbon storage is the presence of a sedimentary basin (Bachu 2003), because it is sedimentary rocks that typically have pore space which can be filled with fluids such as $\mathrm{CO}_{2}$. Porous sandstone and limestone are most typical, although fractures in these rocks or in coal and shale may also store 
fluids. Rocks that do not form part of a sedimentary basin are not considered to be suitable for storage.

The presence of sedimentary rock cropping out at the surface is an indication of a sedimentary basin extending into the subsurface. Basins are typically named after the region in which they crop out. With the exception of the highland areas (Figs. 1-3), sedimentary basins extend across much of New Brunswick, primarily related to the early Paleozoic Matapédia Basin, the late Paleozoic Maritimes Basin, and the Mesozoic Fundy Basin (Fig. 2). These basins are now complex entities divided into an arrangement of connected (e.g., bounded only by syn-sedimentary fault systems) and outlying smaller basins and sub-basins. Some of these divisions are previously defined in the geological literature (e.g., "Sub-basin" capitalized herein, and "Belts"), others are herein informally introduced to aid discussion (e.g., "sub-basin(s)" not capitalized), namely (and Fig. 3):

i. Matapédia Basin Complex:

Connecticut Valley - Gaspé Belt,

ii. Matapédia Basin Complex: Aroostook - Percé Belt

iii. Matapédia Basin Complex: Tobique - Chaleur Belt

iv. Fredericton Belt

v. Maritimes Basin Complex:

Restigouche sub-basins [informal]

vi. Maritimes Basin Complex:

Victoria \& York sub-basins [informal]

vii. Maritimes Basin Complex:

New Brunswick Platform

viii. Maritimes Basin Complex: Cocagne Graben

ix. Maritimes Basin Complex: Moncton Basin

x. Maritimes Basin Complex: Sackville

Sub-basin (incorporating Cumberland Basin)

xi. Maritimes Basin Complex:

Saint John sub-basins [informal]

xii. Maritimes Basin Complex:

Charlotte sub-basins [informal]

xiii. Fundy Basin Complex: Fundy Sub-basin

xiv. Fundy Basin Complex: Grand Manan Sub-basin

Based on earlier assessments (Bachu 2003; Kaldi and Gibson-Poole 2008), the Technical Committee identifies seven general geological criteria relating to the carbon storage potential of sedimentary basins. These criteria are first summarized and then assessed for the fourteen sedimentary basins.

\section{Rock types present}

This criterion relates to whether the sedimentary rock present can act as a seal, or a reservoir (storage). Evaporite rock, such as gypsum, anhydrite, and rock salt are nonporous (no storage potential), but do provide a highly impermeable barrier (seal) to the migration of subsurface fluids. Fine grained clastic rock (mudstone, claystone) most commonly also acts as an impermeable barrier. The more fissile equivalent, shale, is usually a seal but may be fractured on the microscopic scale and act as a fluid store

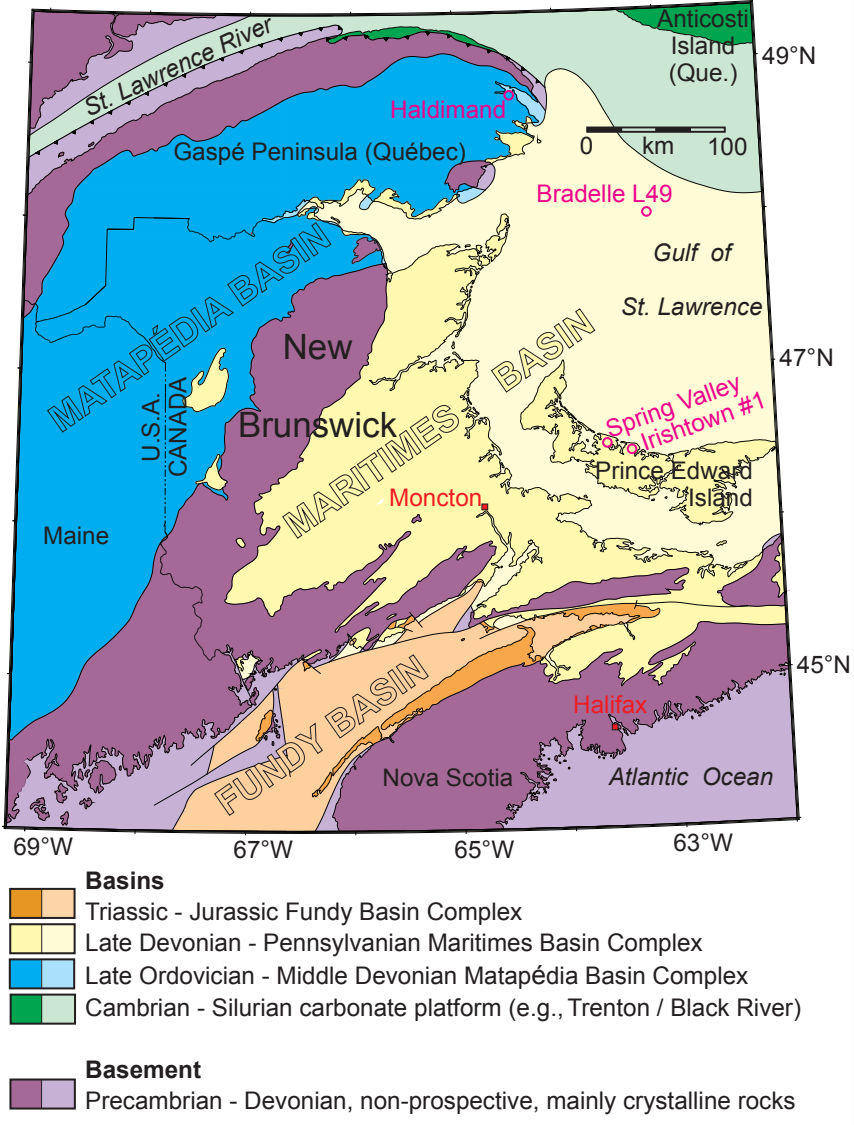

Figure 2. Sedimentary basin complexes of onshore and nearshore New Brunswick and surrounding areas, with location of major exploration boreholes north and east of the province (modified from Keighley and St. Peter 2003; St. Peter and MacIntosh 2005).

(the fracturing may even be engineered). Coal is similarly a potential storage rock when microfractured. Sandstone and, to a lesser extent, carbonate rock (limestone, dolomite) are the typical reservoir rock types and thus the major storage targets. Sedimentary basins in which only shale and evaporite are identified would not be suitable because of the lack of a storage rock, those primarily of sandstone would lack an effective seal. Non-sedimentary rocks, typically (igneous) rocks crystallized from lava flows, may also be interlayered with sedimentary rocks in a basin and act as an impermeable barrier.

The Matapédia Basin Complex and the Fredericton Belt contain both seal (shale) and reservoir (sandstone, limestone) rocks, although commonly these have undergone some degree of metamorphism (Carroll 2003), so reservoir porosity may be lacking. In the Maritimes Basin Complex, the strata are predominantly of sandstone (reservoir), conglomerate, siltstone, mudstone, and shale (seal), locally abundant evaporite (seal), thin limestone, occasionally mineable coal seams (reservoir), and rare basalt (seal). In the Moncton Basin, rocks assigned to the 


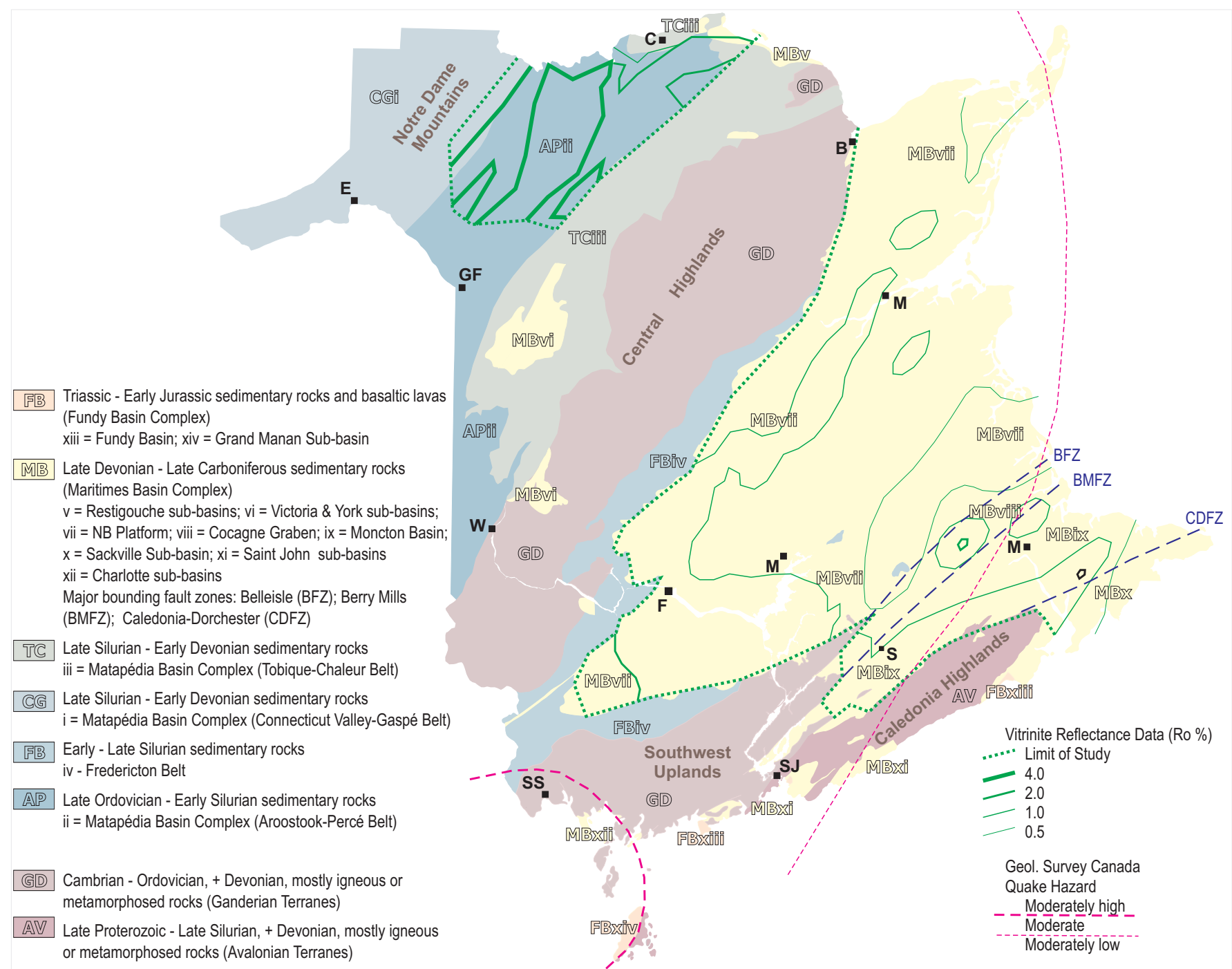

Figure 3. Sedimentary basins and sub-basins of New Brunswick. Map also shows vitrinite reflectance contours (data from St. Peter and MacIntosh 2005; Lavoie et al. 2009) and assessed earthquake hazard (Natural Resources of Canada 2010). See Fig. 1 for abbreviations of place names.

Albert Formation (Horton Group, Mississippian) host the only known petroleum system in onshore Maritime Canada. As such, this Basin has been the focus of most of the fossil-fuel exploration in the province and has by far the most sub-surface information available. Incorporating outcrops on the Nova Scotia side of the Bay of Fundy, the Fundy Basin Complex is known to contain predominantly siltstone, mudstone, some conglomerate and shale (all seal), locally abundant sandstone (reservoir) plus a considerable thickness of basalt (seal).

\section{Surface area}

The surface area is a general two-dimensional representation of the scale of a basin that might reasonably be considered to hold a commercially viable amount of $\mathrm{CO}_{2}$. A successful storage area might have a surface footprint equivalent to as little as $1000 \mathrm{~km}^{2}$ (the approximate surface extent of the Weyburn Field in Saskatchewan). However, an entire basin with such a limited surface area in most cases would not have sufficient volume at depth simply because of basic basin geometry and the thickness of highly porous reservoir rock (and impermeable cap-rock) that would need to be present in the suitable depth window. These constraints need not apply once the surface area of the (sub-) basin exceeds the minimum cut-off of $\sim 5000 \mathrm{~km}^{2}$, provided that the other criteria are supportive. Basins with significantly larger surface area (e.g., $>25000 \mathrm{~km}^{2}$ ) would be most suitable, for they could provide several storage targets in the same vicinity so that, once one storage target is filled, a nearby target could be accessed with minimal additional logistical cost.

The Restigouche, Victoria and York, Saint John, Charlotte and Grand Manan sub-basins each cover a surface area of $<1000 \mathrm{~km}^{2}$, and so could only ever be considered as potential satellite sites to larger storage options that might 
be found in the Matapédia or Fundy basin complexes. The Sackville sub-basin is of similar size, and the Cocagne Graben is $<2000 \mathrm{~km}^{2}$ in size. These two could be potential satellites to options in the Maritimes Basin Complex. The three Matapédia belts, the New Brunswick Platform, Moncton Basin, and Fundy sub-basin are of sufficient areal extent, and also extend into adjacent jurisdictions (Fig. 2), potentially allowing for storage collaborations with other governments.

\section{Depth to basement}

The presence of a shallow basement (metasedimentary rock of an earlier basin or non-sedimentary rock) makes an area unsuitable for $\mathrm{CO}_{2}$ storage. For $\mathrm{CO}_{2}$ to be supercritical requires depths of 800 to $900 \mathrm{~m}$ under normal pressuretemperature gradients. Displacement of methane in the fractures of non-mineable coal requires depths of over $600 \mathrm{~m}$. If a basin is over $1 \mathrm{~km}$ deep, it has obvious potential for both absorption on coal and supercritical fluid storage. This criterion can be directly measured in regions where boreholes have drilled through to basement. Elsewhere, depending on the forces active in forming the basin, depth may be estimated from summation of the vertical thickness of component sedimentary layers at the surface, geophysical analyses, or borehole information.

In the Matapédia belts, seismic data are lacking and only one $200 \mathrm{~m}$ borehole (Notre Dame de Lourdes, Fig. 4) has been drilled in New Brunswick, although the correlative rocks in Québec host the Galt and Haldimand oil fields at $\sim 1.5 \mathrm{~km}$ depth on the eastern Gaspé Peninsula (Fig. 2). Carroll (2003) has calculated that over $12 \mathrm{~km}$ of tilted strata may be present to the west of Campbellton. In the Restigouche, Victoria and York sub-basins, no subsurface data are available and, based on surface structural relationships (e.g., Smith and Fyffe 2006a, b), the rocks are unlikely to extend over $0.6 \mathrm{~km}$ deep. For the Saint John and Charlotte sub-basins, no onshore seismic or borehole data exist. These basins may continue offshore, faulted down below strata of the Fundy Basin Complex but this is based only on marine seismic interpretations (Wade et al. 1996). The remaining basins, from boreholes, gravity maps, and seismic, are known to extend $>1 \mathrm{~km}$ deep over wide areas (e.g., Gussow 1953; Martel 1987; Wade et al. 1996; Waldron

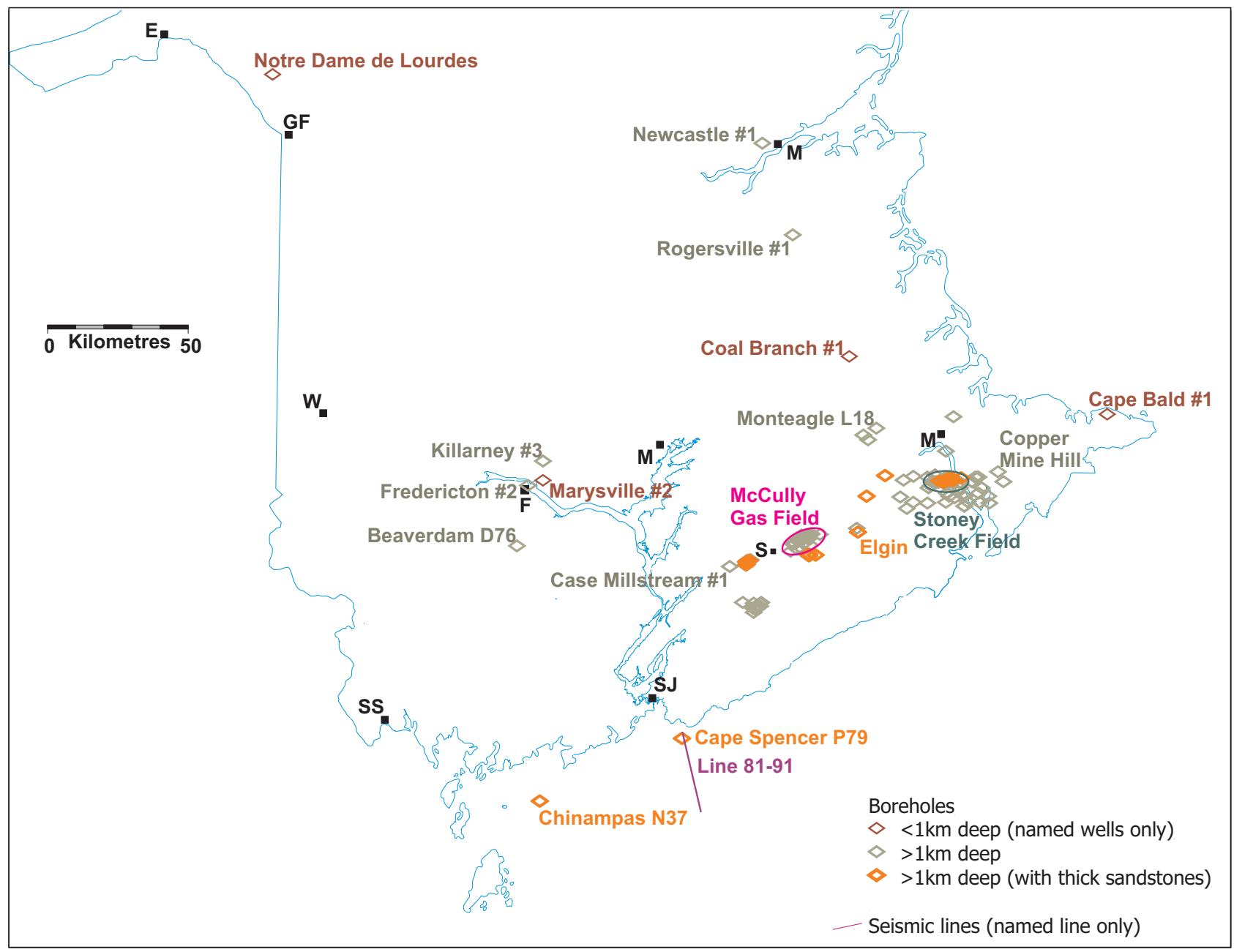

Figure 4. Map of central and southern New Brunswick showing the extent of subsurface exploration boreholes in New Brunswick that have a total depth (TD) over $1 \mathrm{~km}$ with suitable rock types, and other named boreholes and seismic line. 
and Rygel 2005; Wilson and White 2006). However, throughout the Maritimes Basin Complex, and particularly in the New Brunswick Platform, several boreholes have also encountered faulted and uplifted blocks of basement rock at depths of $<500 \mathrm{~m}$ (e.g., Coal Branch \#1 borehole, $\sim 50 \mathrm{~km}$ ENE of Minto; Cape Bald \#1 borehole penetrating the Westmorland Uplift, east of Moncton, St. Peter and Johnson 2009; Fig. 4).

\section{Current thermal regime}

This is another indicator of the depth at which $\mathrm{CO}_{2}$ will behave as a supercritical fluid. Measured in the subsurface either via a mineshaft or borehole, low temperature gradients $\left(<30^{\circ} \mathrm{C} / \mathrm{km}=\right.$ cold basins $)$ require deeper storage for the $\mathrm{CO}_{2}$ to be in a supercritical state than where the temperature gradient is steeper $\left(>40^{\circ} \mathrm{C} / \mathrm{km}=\right.$ warm basins $)$. Unpublished data from the McCullygas field in the Moncton Basin (New Brunswick Department of Energy and Mines, borehole files) indicate that the basin is cold and this likely is also the case for all the other basins onshore. Similarly for the Fundy Basin Complex, unpublished data indicate a maximum geothermal gradient of only $24.4^{\circ} \mathrm{C} / \mathrm{km}$.

\section{Maximum basin-burial temperature and compaction}

This is an indicator of the maximum temperature (proxy for depth) to which the rock has ever been buried. High temperatures $\left(>225^{\circ} \mathrm{C}\right)$ and burial depth usually indicate more pore spaces have been filled by mineral cements, leaving a lower quality reservoir for storage. Similarly, the onset of metamorphic processes and cleavage development indicates high temperature and pressure and thus limited remnant porosity. The maximum temperature for oil generation is $\sim 175^{\circ} \mathrm{C}$; above which only natural-gas fields would be available to maintain pressure regimes. Maximum burial values can be calculated at the surface by looking at how "cooked" any contained fossil plant material (vitrinite) appears (Fig. 3). If rocks now uplifted back to the surface have previously been buried to a particular depth (temperature), underlying rocks in the subsurface should have been at least as hot.

Detailed vitrinite reflectance data have been presented for parts of the Matapédia and Maritimes basin complexes (Fig. 3) by St. Peter and MacIntosh (2005) and Lavoie et al. (2009). Data only exist for the northeastern third of the Matapédia Basin Complex and most surface rocks are thermally overmature. Only in the Tobique - Chaleur Belt, and specifically limited to the small area east and west of Campbellton, do vitrinite data suggest the rocks at the surface have only been buried down into the oil or condensate window, i.e., vitrinite reflectance, Ro, $<2.0 \%$ $=<200^{\circ} \mathrm{C}$. In the New Brunswick Platform, data indicate an east to west trend of increasing thermal maturity, from the upper oil window $(0.6 \%$ Ro) to the upper gas window $(1.5 \%)$, with only the far southwestern corner potentially overcooked and unsuitable, with surface rock having been at $>2.0 \%$ Ro. In the Cocagne Graben, Moncton Basin and Sackville sub-basin, surface vitrinite values are mostly in the oil and gas window, although there are anomalous locations along the basins' mutual boundaries (the Berry Mills fault system including the Indian Mountain Deformed Zone, and the Caledonia - Dorchester fault system, Fig. 3) where higher values are recorded. Data from the two boreholes drilled in the Fundy Sub-basin indicate vitrinite reflectance of around 0.5 , and 0.8 close to the base of the drilled sections ( $3 \mathrm{~km}$ depth).

Carroll (2003) observed graphitic slate in the Aroostook - Percé Belt and widespread cleavage in the Connecticut Valley - Gaspé Belt, which support the high vitrinite data for the Matapédia Basin Complex and indicate that little porous storage rock will exist at depth. Cropping out along much of the southwestern and western margin of the New Brunswick Platform are additional Silurian strata assigned to the Fredericton Belt (Fig. 3). These rocks, likely continuous below at least the western half of the New Brunswick Platform, are also sedimentary in origin. However, they are not discussed in detail in this report because they widely display metasedimentary features such as cleavage (e.g., Park and Whitehead 2003), and can be considered the local basement. In the Cocagne Graben outcrop, Horton Group rocks locally also exhibit slight cleavage in the Indian Mountain Deformed Zone (Park and St. Peter 2008).

\section{Faults}

The presence of a large number of faults in an area, if sealed, would result in greater compartmentalization of the storage reservoir. More drilling would be required in order to penetrate the large number of small storage compartments that would need to be filled separately. Conversely, there is the possibility that some of the faults might not be sealed, which could lead to leakage of the stored gas if a fault cut through the cap rock or the fault formed part of the (supposed) seal. Basins that have been subject to a greater number of tectonic episodes, or deformation events, are typically more extensively faulted and thus less suited for storage.

Several deformation events are identified in the Matapédia Basin Complex (e.g., Wilson and Kamo 2012) and based on bedrock geological maps and reports, folding and faulting is inferred to be extensive. Similarly, the Maritimes Basin Complex has undergone numerous deformation events but most were intermittent with sedimentation in the basin (Wilson and White 2006; Park et al. 2007). Accordingly, Horton Group strata at the base of the Mississippian succession may have been subject to four or more deformational events (Park et al. 2007; Park and St. Peter 2008) whereas latest Pennsylvanian strata, widespread across the New Brunswick Platform, are mostly undeformed (e.g., St. Peter 2005; Smith and Fyffe 2006c). 
Early Pennsylvanian tectonics involved the formation of salt walls and diapirs in the Moncton and Sackville basins (Waldron and Rygel 2005; Wilson and White 2006). Seismic data from the Fundy Basin Complex indicate that faulting is relatively sparse (e.g., Wade et al. 1996) and primarily related to basin-bounding faults that have undergone only one phase of mostly extensional movement.

\section{Current tectonics (earthquakes)}

Movements on faults that cross a basin (earthquakes) would be a problem for pumping and storage infrastructure located at the surface, as well as posing a concern for storage reservoir integrity if the fault formed part of, or cut through what might be considered the seal of a saline reservoir. An historical earthquake record for the province has been documented by Burke (2009) and Natural Resources Canada (2010) has issued a national earthquake hazard map that includes New Brunswick (Fig. 3).

The hazard map indicates that most of the province has an acceptable moderate to moderately low risk of a major ( $>6$ magnitude) earthquake. However, the risk south of St Stephen is rated moderately high, being close to a documented 5.9 earthquake epicentre (Burke 2009).

\section{SUBSURFACE GEOLOGICAL CRITERIA}

In terms of the general geological criteria that can be retrieved from surface and existing subsurface data, most sedimentary basins in New Brunswick appear to have minimal potential for carbon storage. Several basins belonging to the Maritimes and Fundy basin complexes are simply too small in surface area and also lack subsurface information (basins v, vi, viii, $x, x i$, xii, and xiv). The belts of the Matapédia Basin Complex (basins i, ii, and iii) and the Fredericton Belt (basin iv) are thermally overmature or tightly folded, faulted and cleaved, or both.

Review of the sedimentary basins with a more favourable storage outlook, namely the New Brunswick Platform (basin vii) Moncton Basin (basin ix), and Fundy Sub-basin (basin xiii), can be taken a stage further. Strictly, this requires applying broad numeric values to various equations. These equations collectively indicate the volume of $\mathrm{CO}_{2}$ that can ultimately be stored at depth and whether this volume can be filled at a flow rate similar to the production of $\mathrm{CO}_{2}$ by the LFEs (e.g., Martinez et al. 2009). Not all of the required values are available for any of the basins in New Brunswick (e.g., data on seals and trapping structures). However, at this preliminary stage, and following Bachu (2003 and unpublished), Bradshaw et al. (2007), Chadwick et al. (2008), many of the required values instead can be simplified into a ratings system and tabulated (Tables 1 and 2). The presence of regional seals and trapping structures for oil, gas, and saline reservoirs are not assessed.

\section{New Brunswick Platform (basin vii)}

Properties of subsurface strata in the Platform are known from numerous boreholes, but supplemented by only a few seismic lines (Fig. 1). Several of these boreholes reached basement at less than $250 \mathrm{~m}$ depth, indicating that large portions of this region are unsuitable for storage. The strata offshore are known only by extrapolation downdip from the onshore, and from one borehole offshore Québec in the vicinity of New Brunswick's jurisdiction (Bradelle L-49, Fig. 2). No boreholes have been drilled in New Brunswick waters.

\section{Coal}

Coal has been surface mined around Minto. Although numerous boreholes have been drilled in the central lowlands, sporadically identifying coal at shallow depths (Fig. 1) only fifteen have been drilled over $600 \mathrm{~m}$ deep (Wilson and Ball 1983). Of these, only the Marysville \#2 (Fig. 4) well report contains reference even to coal stringers (thin discontinuous material of no storage potential) at a depth of more than $400 \mathrm{~m}$. At $100 \mathrm{~km}$ offshore, in the Bradelle L- 49 well, a coal-bearing interval occurs between $1.5-1.9 \mathrm{~km}$ depth. Assuming this is the same coal interval

Table 1. Specific geological criteria for carbon storage potential in coal beds (adapted from Bachu 2003; Bachu et al ., 2007; Bradshaw et al ., 2007). For all basins in New Brunswick, the preliminary assessment rating $=1$.

\begin{tabular}{|c|c|c|c|}
\hline \multirow[t]{2}{*}{ CRITERIA } & \multicolumn{3}{|c|}{ RATINGS } \\
\hline & 1 & 2 & 3 \\
\hline Presence of seams & unknown & $\begin{array}{l}\text { yes } \\
\text { (depends on sub-criteria) }\end{array}$ & $\begin{array}{l}\text { yes } \\
\text { (depends on sub-criteria) }\end{array}$ \\
\hline - Depth & $<600 \mathrm{~m} \&>1000 \mathrm{~m}$ & & $600-1000 \mathrm{~m}$ \\
\hline - Salinity & $<30000 \mathrm{mg} / \mathrm{L}$ & $30000-100000 \mathrm{mg} / \mathrm{L}$ & $>100000 \mathrm{mg} / \mathrm{L}$ \\
\hline - Coal rank & Anthracite & Lignite & Bituminous \\
\hline - Coal value & Economic & & Uneconomic \\
\hline - Fractures/cleats? & no & & yes \\
\hline
\end{tabular}




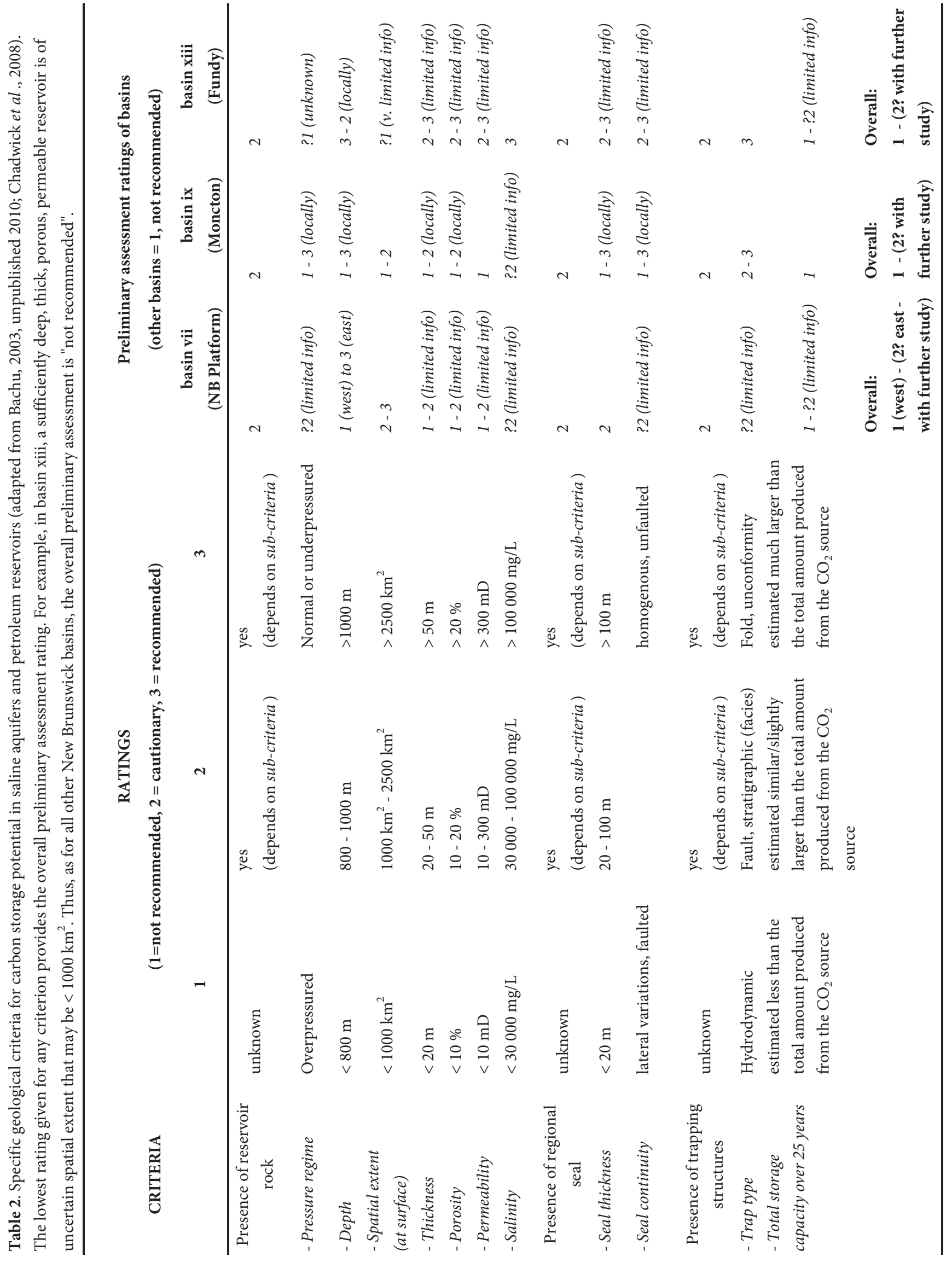


as at Minto, if continuous, the coal may be at appropriate depth under coastal areas of northeastern New Brunswick. No analyses of these coals were found in a brief literature search and no further analysis can be undertaken. As a result, although there are positive indicators much exploratory work is needed before a cautionary recommendation can be given.

\section{Oil, gas, or saline reservoirs}

Only five of the $270+$ boreholes in the Platform have been drilled below $1 \mathrm{~km}$ depth (Fig. 4). Although Fredericton \#2 borehole (Total Depth, TD, $1102 \mathrm{~m}$ ) was not cored, it is reported to have wireline information recorded, including lithologic and porosity logs; however, none were found during this study. No wirelines were taken for the Rogersville \#1 well (basement below $692 \mathrm{~m}$ ), Newcastle \# 1 (basement below $986 \mathrm{~m}$, with only $<1 \mathrm{~m}$ thick sandstone interbeds present below $812 \mathrm{~m}$ ), and Killarney \#3 (TD in shale at $\sim 1050 \mathrm{~m}$ but no sandstone below $960 \mathrm{~m}$ ). For the Beaverdam D-76 well, the uppermost $\sim 1 \mathrm{~km}$ is assigned to the coal-bearing Pictou Group below which is a succession of volcanic rocks, meta-sedimentary rocks, and dolomite of unknown stratigraphy.

The Bradelle L-49 well, offshore Québec, drilled through much of the stratal succession belonging to the Maritimes Basin Complex (Hu and Dietrich 2008): $2800 \mathrm{~m}$ of Pennsylvanian strata and $1534 \mathrm{~m}$ of Mississippian strata (including Horton Group). Cored sandstone of the Pennsylvanian Pictou Group at 960-970 $m$ depth produced marginally suitable porosities $(\phi)$ of $10-20 \%$, and permeabilities $(\mathrm{k})$ of $10-100 \mathrm{mD}$. The thickest sandstone intervals at similar depths are suitably 15-40 $\mathrm{m}$ thick. With increasing depth to $1.4 \mathrm{~km}$, however, the sandstone units thin and permeabilities (from wireline logs only) appear to max-out at around $10 \mathrm{mD}$. If the burial related compaction and cementation occurs basinwide at similar depths (Lavoie et al. 2009), sandstone below 1.4 $\mathrm{km}$ that has low porosity in Bradelle L- 49 may be of better quality where it is at shallower depth in New Brunswick's jurisdiction.

Following the assessment criteria of Table 2, for offshore New Brunswick, these Pennsylvanian sandstone units would produce a "cautionary recommendation" in terms of depth, thickness, porosity and permeability. More problematic would be the integrity of the seal in the form of the interbedded mudstone. Well-log analysis indicates that even the $60 \mathrm{~m}$ thick mudstone beds are not homogenous, but have an appreciable sand content (sandy mudstone or thin sandstone stringers).

\section{Moncton Basin (basin ix)}

Subsurface strata in the Moncton Basin (and to a lesser extent the potential satellite areas in the Cocagne Graben and Sackville sub-basin of the Maritimes Basin Complex) are the best understood in the province. There is both extensive seismic and borehole information available (Fig. 1) because the Basin hosts the only known petroleum system onshore Maritime Canada, and has been the focus of petroleum exploration (e.g., Stoney Creek Oil and Gas Field, McCully Gas Field, Fig. 4). The petroleum is present in the Albert Formation (Horton Group), which lies near the base of the Mississippian stratal succession. There is only sparse seismic offshore in the Northumberland Strait, but data also can be extrapolated from onshore PEI (e.g., Irishtown \# 1, Spring Valley, Fig. 2).

\section{Coal}

As was the case in the Platform, although numerous boreholes have been drilled in the Moncton Basin, no associated reports refer to coal below $600 \mathrm{~m}$. On PEI, the Irishtown \#1 well encountered coal at the optimal depth of $800-1100 \mathrm{~m}$ suggesting storage might also be available at appropriate depth in the Northumberland Strait. Again, much exploratory work is needed before a recommendation can be given.

\section{Oil, gas, or saline reservoirs}

Over 100 boreholes in the southeast have been drilled to below $1 \mathrm{~km}$ depth (Fig. 4). This is supplemented by a similar number of 2D seismic lines (of highly variable quality) and some $3 \mathrm{D}$ coverage associated with the petroleum finds and potash exploration.

The McCully field accounts for nearly $40 \%$ of deep boreholes in the region. It has several characteristics beneficial to storage, such as a low thermal gradient, stacked Albert Formation sandstone packages below $2 \mathrm{~km}$ depth (although individual beds may be under $40 \mathrm{~m}$ thick) and a combined doubly folded-unconformity trap (Durling and Martel 2003). Seismic results indicate that strata from beneath the currently producing pools have a spatial extent around the minimum required $\left(1000 \mathrm{~km}^{2}\right)$ but there are other, more detrimental factors. The Albert Formation rock is extensively faulted (Wilson and White 2006), resulting in compartmentalized reservoirs. The field is overpressured (3500 kpa, or 500 psi, above hydrostatic; Martel and Durling 2001) and pressure stimulation is not going to be required over the next 30-40 years because formation pressures are expected to decline slowly (Martel, pers. comm., 2008). Porosities are low with values mostly $<10 \%$ (e.g., in the J-65 well, maximum core analysis $\phi=10.4 \%$ at $2695 \mathrm{~m}$ ). Permeabilities are very low, classifying the field as a "Tight Gas Sand" play with values mostly $<5 \mathrm{mD}$ (e.g., maximum core analysis $\mathrm{k}=3.25 \mathrm{mD}$ at $2697 \mathrm{~m}$ in J-65). There is also unusually low residual water saturation of $\sim 10 \%$ (Martel and Durling 2004). The adjacent Caledonia oil field is still under evaluation, and so data from this location remains confidential. However, there is little reason to suspect all of the aforementioned problems with McCully would 
disappear across only a few kilometres distance. With respect to potential saline reservoirs, strata overlying the Albert Formation in the vicinity of McCully include what from seismic and field mapping relationships appear to be much less extensively faulted mudstone, sandstone, and conglomerate of the overlying Mississippian Sussex Group that are all below $1 \mathrm{~km}$ depth. Unfortunately, these rocks have not been cored and wireline logs do not indicate the presence of thick porous and permeable reservoir sandstone.

An additional $40 \%$ of the deep boreholes have been drilled on or around the Stoney Creek field. The field itself is located at shallow depths $(600-900 \mathrm{~m})$, and so is unsuitable for storage. Several deeper exploration boreholes (on strike east and west, or down dip to the south) searching for additional pools and satellite fields have encountered Albert Formation or underlying Mississippian sandstone below $1 \mathrm{~km}$ depth that could act as a saline reservoir. Taking into account deep boreholes on both sides of the Petitcodiac estuary, the surface area criterion could be met, but the number of major faults running $\mathrm{E}-\mathrm{W}$ through the area pose a major problem of reservoir discontinuity or leakage (e.g., St. Peter and Johnson 2008). Also, although porosities are generally suitable, reservoir thickness and permeabilities are a concern. In the 1985 IOL Stoney Creek \#1 well (Fig. 4; TD $1592 \mathrm{~m}$ ), core analysis from sandstone at $955-991 \mathrm{~m}$ indicates maximum $\phi=12 \%$ and $\mathrm{k}=2.84$ $\mathrm{mD}$. Numerous deeper sand bodies, particularly between 1550-1570 m were not cored but in the sister East Stoney Creek \#1 well (TD $1435 \mathrm{~m}$ ) neutron porosity logs infer values of $15-30 \%$ in sandstone beds at $1167-1175 \mathrm{~m}$ and 1392-1400 m. Data from Albert Mines L-44 (TD 2050 m), in a small fault block southeast of Stoney Creek, is restricted to a neutron porosity log, but suggests $20-30 \%$ porosity between 1030-1050 m, with values above $15 \%$ sporadically down to $2 \mathrm{~km}$ (assuming correct calibration).

Albert Formation strata have also been drilled at depth in the Elgin area. As with the Albert Formation elsewhere, seismic indicates the presence of numerous faults detrimental to reservoir continuity and the limited core

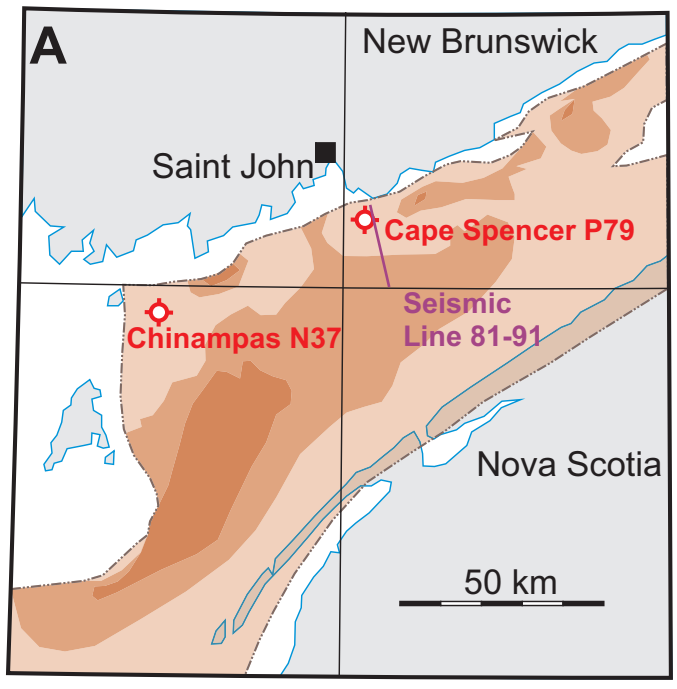

Depth to top North Mountain Basalt surface $<1 \mathrm{~km}$ $<2 \mathrm{~km}$ $>2 \mathrm{~km}$

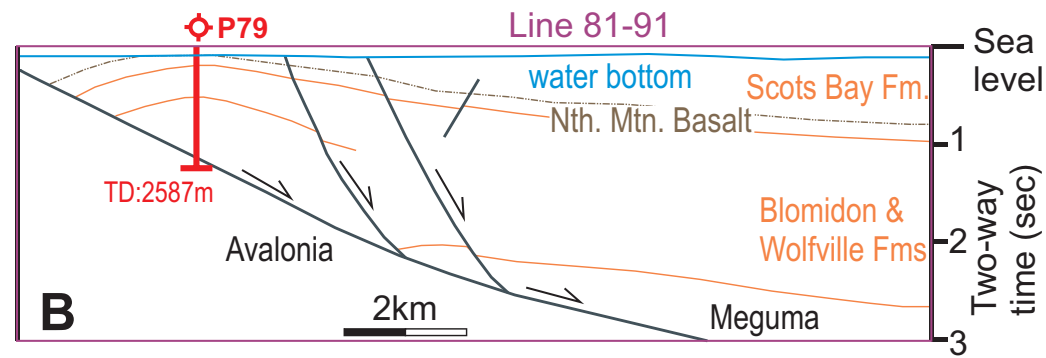

and wireline data are not promising. The Lee Brook \# 1 well (TD $2100 \mathrm{~m}$ ) has been sparsely cored and data from 984$999 \mathrm{~m}$ show maximum $\phi=9.9 \%$ and maximum $\mathrm{k}=1.4 \mathrm{mD}$ (in contrast, wireline data indicate $2 \mathrm{~m}$ of sandstone with over $30 \%$ porosity in this interval). For the Will De Mille \#1 well (TD $2644 \mathrm{~m}$ ), porosities calculated from wireline data indicate the presence of highly porous $(>20 \%)$, but thin $(<5$ $\mathrm{m}$ thick) sandstone beds at 1558-1563 m depth.

Elsewhere in the region, the other deep boreholes have conclusively identified only strata from higher up in the Carboniferous succession. The relative advantage of such rocks is that they have been subject to progressively fewer episodes of deformation and so faulting is less extensive. The downside is that the sandstone and limestone encountered were not the target rocks for the exploration and so corerelated data are generally lacking. In the Cocagne Graben, the Monteagle L-18 well (TD $1977 \mathrm{~m}$ ) has $\phi>10 \%$ recorded across $11 \mathrm{~m}$ of section between $900-1000 \mathrm{~m}$ but at greater depths sandstone beds are not sufficiently thick nor abundant. Other Monteagle cores have open fractures and faults. On PEI, the Spring Valley well indicates porosities of $12-20 \%$ in sandstone at $1.0-1.3 \mathrm{~km}$ depth (Lavoie et al. 2009). The nearby Irishtown well has slightly lower logcalculated porosities.

Several of the assessment criteria of Table 2 locally are met for Moncton Basin strata (depth, thickness, porosity) but when considered collectively and with spatial extent and pressure regime also accounted for, the basin would still require further investigation before it is given a "cautionary recommendation".

\section{Fundy Sub-basin (basin xiii)}

Subsurface strata in the Bay of Fundy are of Mesozoic age and form part of the Fundy Basin Complex. Neither coal nor petroleum has been encountered to date, and so the only targets are saline reservoirs. Although there is broad seismic coverage, borehole information is limited to two wells (Figs. 1, 5, 6).

Figure 5. (A) Map of the western Fundy Sub-basin showing the location of the Cape Spencer well and (B) interpreted seismic line (81-91) through the Mesozoic stratal succession. On the map, the area shaded in brown illustrates the potential area in which the North Mountain Basalt is at sufficient depths to provide an additional seal. Modified from Wade et al. (1996).

A preliminary assessment of carbon storage suitability in deep underground geological formations of New Brunswick, Canada 


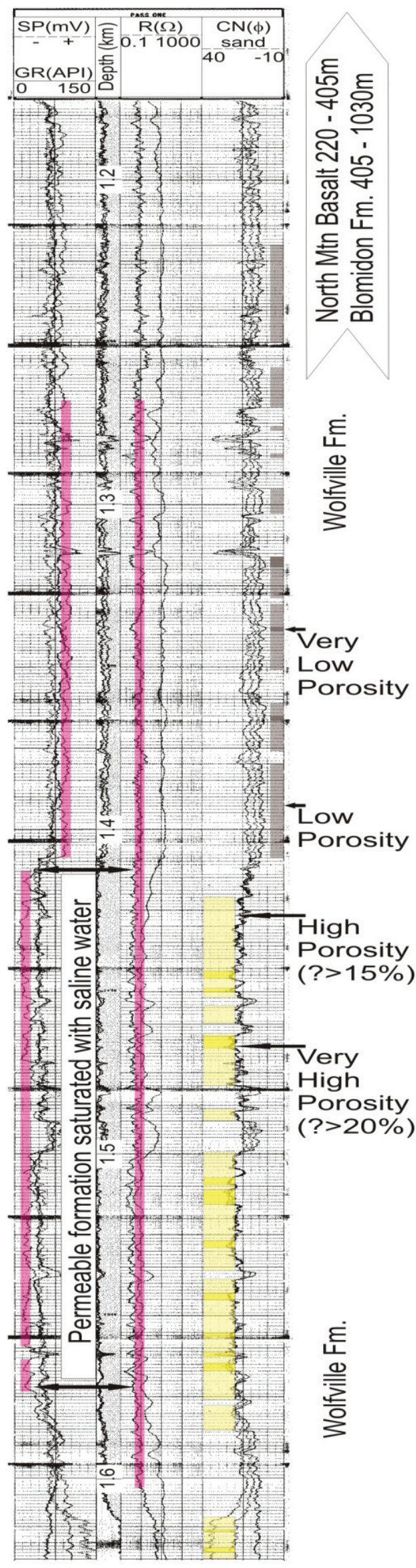

Figure 6. Annotated wireline responses for the interval from 1175 to $1625 \mathrm{~m}$ depth in the Cape Spencer \#1 well. In track 1, the Self Potential (SP) kicks to the left (pink highlight) indicating a permeable interval, with the similar kick in the Gamma Ray (GR) indicating low clay and $\mathrm{K}$-feldspar content, e.g., quartz arenite sandstone. In track 2, the lack of an equivalent kick to the right in the resistivity (R: pink highlight) indicates the permeable interval is of saline water. In track 3 , high (pale yellow) and very high (yellow) porosities are indicated by the compensated neutron porosity $(\mathrm{CN}) \log$.

\section{Saline reservoirs}

Both wells drilled in the Bay of Fundy had core recovered, but not from intervals of relevance to a carbon storage assessment. As noted by Wade et al. (1996), wirelines from the Chinampas N-37 well indicate a cumulative thickness of $280 \mathrm{~m}$ of reservoir sandstone but porosities are suggested to range between only $3-16 \%$. Formation salinities were high $\left(125000 \mathrm{ppm} \mathrm{Cl}^{-}\right)$. In contrast, the Cape Spencer P-79 well (Fig. 6) contained less cumulative sandstone, but particularly in the interval between $~ 1200$ $1600 \mathrm{~m}$, very suitable storage conditions are inferred from wireline data. Wolfville Formation sandstone porosities, potentially between $15-25 \%$, along with a good indication of permeability exist from 1500-1536 and 1538-1575 m (36 and $37 \mathrm{~m}$ continuous thickness, Fig. 6). These values are supported by descriptions of the drill cuttings, which indicate unconsolidated sand and therefore a lack of porefilling cement. Overlying rocks appear to be predominantly low porosity (and permeability) shale that can be continuous (no interbedded sandstone) for over $30 \mathrm{~m}$ thickness to provide a seal. Also, as shown in Wade et al. (1996, and Fig. 5), the well was drilled through a partly fault bounded anticline that likely provides a trap of sufficient spatial extent at the required depths. No documentation was found that indicates the pressure regime. The major limitation at the moment is the uncertainty regarding the spatial extent for the actual trap, and thus uncertainty of total storage capacity: the borehole represents the only point containing subsurface Wolfville Formation data within a $50 \mathrm{~km}$ radius. The only other borehole, Chinampas N-37, does not contain such high quality reservoir sandstone. If the sandstone was laterally persistent to the south and east of these boreholes, the North Mountain Basalt would additionally be available to act as a regional seal (Fig. 5).

\section{SUMMARY}

New Brunswick would be a suitable location for $\mathrm{CO}_{2}$ storage given that it has several point industrial sources (Large Final Emitters) currently releasing $\mathrm{CO}_{2}$ into the atmosphere and contributing to Canada's greenhouse gas emissions. The entire onshore and offshore jurisdictions 
would be in close enough proximity for economic transport by pipeline of captured and compressed $\mathrm{CO}_{2}$. The pipeline would not be subject to a detrimental climate and any route would likely be sufficiently accessible and could readily be built by local industry and workforce. The regulatory status is generally in place but clarification would be needed regarding wording in the existing Underground Storage Act, and whether joint federal-provincial governance might be required for oversight in the Bay of Fundy. An existing petroleum industry has also allowed for more detailed local geological assessment of storage potential.

New Brunswick contains several upland and highland regions where the basic geological criteria for storage in the subsurface are not met. Many of the surface rocks in the northwestern half of the province (roughly demarked by the area northwest of a line running from Fredericton to Bathurst) are of "basement" igneous or metamorphic rock. Similar rock types are prevalent in the Caledonia Highlands and SW Uplands. Sedimentary basins are present in these regions but are mostly of metamorphosed sedimentary rock (Matapédia Basin Complex), or of a scale too small for subsurface storage (Restigouche, Victoria, Saint John and Charlotte sub-basins of the Maritimes Basin Complex).

Large expanses of sedimentary rock, of various types that can act as either the reservoir or the seal, constitute sedimentary basin fill of the New Brunswick Platform, Moncton Basin (including adjacent Cocagne Graben and Sackville Sub-basin) and Fundy Basin. These rocks underlie most of the remainder of the province as well as regions of the Gulf of St. Lawrence, Northumberland Strait, and Bay of Fundy that are under New Brunswick jurisdiction. Seismic and borehole (well) information in these regions confirms that, at least in part, the potential reservoir and seal rocks previously have not been buried too deeply and currently can extend to over $1 \mathrm{~km}$ depth in generally cold basins $\left(<30^{\circ} \mathrm{C} / \mathrm{km}\right.$ temperature gradient). Under the aforementioned conditions and depth, $\mathrm{CO}_{2}$ storage potential is enhanced because the $\mathrm{CO}_{2}$ molecules can then behave a supercritical fluid and be more efficiently stored. The potential is somewhat less favourable in the western Bay of Fundy near Grand Manan because of a greater earthquake hazard that might affect infrastructure or fault seal of the storage reservoir.

The assessment of additional geological criteria necessary for the successful storage of $\mathrm{CO}_{2}$ in subsurface coal seams, depleted oil and gas reservoirs, or saline (nonpotable) aquifers requires information from the storage depths. No boreholes currently penetrate any of these seams, reservoirs, or aquifers at required depths in the New Brunswick Platform or its continuation offshore. Information gathered from boreholes at slightly shallower depth in the Platform, and downdip in boreholes drilled under neighbouring Québec and PEI jurisdictions, indicate that suitable rocks could be present along New Brunswick's eastern and northern coastlines. However, until such time (following exploratory geophysical and borehole surveys) that supportive subsurface data become available, these regions of the province cannot be recommended for $\mathrm{CO}_{2}$ storage.

The Moncton Basin contains the only commercial petroleum fields in onshore Maritime Canada. However, the McCully Gas Field is a long way from being depleted and, regardless, is hosted in tight gas sands where it would be difficult to pump down $\mathrm{CO}_{2}$ at an economical rate. The Stoney Creek Oil and Gas Field is not at sufficient depth for $\mathrm{CO}_{2}$ to be in its supercritical state. Saline reservoirs, with no associated economic benefit from petroleum extraction, could underlie suitably large areas around these fields, or offshore to the east. There are limited reliable data on the quality of the potential reservoir rock and the data indicate only moderate porosity and permeability. Most of the available data are also from the oldest (typically deepest buried) sedimentary rock (Horton Group) that has undergone the most deformation (faulting). This would be detrimental to a storage program because faults separate the reservoir into small compartments, each of which would have to be separately filled, further increasing the expense. Faults might also transect the seal where they could act as conduits for $\mathrm{CO}_{2}$ leakage. Younger strata at suitable depth could represent stores and seals, but until more core is taken and analyzed from such rocks, their suitability is not confirmed. Accordingly, these regions of the province currently cannot be recommended for $\mathrm{CO}_{2}$ storage.

Strata underlying the Bay of Fundy have characteristics that support a cautious recommendation for carbon storage in terms of trap type; a reservoir with suitable thickness, salinity, and wireline-calculated porosity and permeability; a seal with suitable thickness; and limited faulting to potentially compartmentalize the reservoir or, conversely, compromise the continuity of the seal. However, this location, south of Saint John, is currently of uncertain pressure regime and trap volume. The porosities and permeabilities need to be confirmed by analysis of core that, as yet, does not exist. In the case of trap volume, the problem is compounded because the prospect is identified from only a single data point (the Cape Spencer P-79 well). There is no commercial by-product (petroleum, coal) currently identified and so development would be costly. Until such time (following further exploratory geophysical and borehole surveys: of considerable expense in offshore areas, and to be conducted in an environmentally sensitive area), this region of the province also cannot yet be recommended for $\mathrm{CO}_{2}$ storage.

\section{ACKNOWLEDGEMENTS}

M. Malo, an anonymous reviewer, and editor $\mathrm{M}$. Parsons provided detailed and constructive comments. L. Fyffe, S. Hinds, J. MacIntosh, and support staff at the New Brunswick Department of Energy and Mines are thanked for facilitating access to many unpublished drilling reports and for temporary workspace. W. Gunter is thanked 
for discussion and encouragement, as are the Technical Committee for the "National Atlas of $\mathrm{CO}_{2}$ Storage Capacity in Canada", particularly J. MacDonald and the chair, S. Bachu.

\section{REFERENCES}

Andrew, M., Bijeljic, B., and Blun, M.J. 2013. Pore-scale imaging of geological carbon dioxide storage under in situ conditions. Geophysical Research Letters, 40, pp. 3915-3918. http://dx.doi.org/10.1002/grl.50771

Bachu, S. 2003. Screening and ranking of sedimentary basins for sequestration of $\mathrm{CO}_{2}$ in geological media in response to climate change. Environmental Geology, 44, pp. 277-289. http://dx.doi.org/10.1007/s00254-0030762-9

Bachu, S., Bonijoly, D., Bradshaw, J., Burruss, R., Holloway, S., Christensen, N.P., and Mathiassen, O.M. 2007. $\mathrm{CO}_{2}$ storage capacity estimation: methodology and gaps. International Journal of Greenhouse Gas Control, 1, pp. 430-443. http://dx.doi.org/10.1016/S17505836(07)00086-2

Bradshaw, J., Bachu, S., Bonijoly, D., Burruss, R., Holloway, S., Christensen, N.P., and Mathiassen, O.M. 2007. $\mathrm{CO}_{2}$ storage capacity estimation: issues and development of standards. International Journal of Greenhouse Gas Control, 1, pp. 62-68. http://dx.doi.org/10.1016/S17505836(07)00027-8

Burke, K.B.S. 2009. Historical earthquakes felt in New Brunswick (1764, 1811-1960). Sandler Geophysical, Fredericton, New Brunswick, 755 p.

Caldeira, K. and Wickett, M.E. 2003. Anthropogenic carbon and ocean pH. Nature, 425, p. 365. http://dx.doi. org $/ 10.1038 / 425365$ a

Carroll, J.I. 2003. Geology of the Kedgwick, Gounamitz River, States Brook and Menneval map areas (NTS 21 $\mathrm{O} / 11,21 \mathrm{O} / 12,21 \mathrm{O} / 13$, and $21 \mathrm{O} / 14)$, Restigouche County, New Brunwick. In Current research 2002. Edited by B.M.W. Carroll, New Brunswick Department of Natural Resources, Mineral Resource Report 2003-4, pp. 23-37.

Chadwick, A., Arts, R., Bernstone, C., May, F., Thibeau, S., and Zweigel, P. 2008. (Compilers and Editors) Best practice for the $\mathrm{CO}_{2}$ storage in saline aquifers - observations and guidelines from the SACS and CO2STORE Projects. British Geological Survey, Nottingham, U.K., 289 p.

Durling, P. and Martel, T. 2003. The McCully gas field; a proven resource with high exploration potential. Geological Society of America, Northeastern Section, 38th annual meeting, Halifax, 2003, p. 81.

Emberley, S., Hutcheon, I., Shevalier, M., Durocher, K., Mayer, B., Gunter, W., and Perkins, E. 2005. Monitoring of fluid-rock interaction and $\mathrm{CO}_{2}$ storage through produced fluid sampling at the Weyburn $\mathrm{CO}_{2}$-injection enhanced oil recovery site, Saskatchewan, Canada. Applied Geochemistry, 20, pp. 1131-1157. http://dx.doi. org/10.1016/j.apgeochem.2005.02.007

Environment Canada. 2014. National inventory report 1990-2012: greenhouse gas sources and sinks in Canada - executive summary, $12 \mathrm{p}$.

Gunter, W.G., Perkins, E.H., and Hutcheon, I. 2000. Aquifer disposal of acid gases: modeling of water-rock reactions for trapping of acid waters. Applied Geochemistry, 15, pp. 1086-1096. http://dx.doi.org/10.1016/S08832927(99)00111-0

Gussow, W.C. 1953. Carboniferous stratigraphy and structural geology of New Brunswick, Canada. American Association of Petroleum Geologists Bulletin, 37, pp. 1713-1816.

Hu, K. and Dietrich, J. 2008. Evaluation of hydrocarbon reservoir potential in Carboniferous sandstones in six wells in the Maritimes Basin, Eastern Canada. Geological Survey of Canada, Open File 5899, 18 p. http://dx.doi.org/10.4095/226167

International Panel on Climate Change.2013.Stocker, T.F., D. Qin, G.-K. Plattner, M. Tignor, S.K. Allen, J. Boschung, A. Nauels, Y. Xia, V. Bex and P.M. Midgley (Editors). Climate change 2013: The physical science basis. Contribution of Working Group I to the Fifth Assessment Report of the Intergovernmental Panel on Climate Change, Cambridge University Press, Cambridge, United Kingdom and New York, NY, USA, 1535 p.

Kaldi, J.G. and Gibson-Poole, C.M. (Editors). 2008. Storage capacity estimation, site selection and characterisation for $\mathrm{CO}_{2}$ storage projects. Report No: RPT08-1001, CO2CRC, Canberra, ACT, Australia, 60 p.

Kaszuba, J.P., Janecky, D.R., and Snow, M.G. 2005. Experimental evaluation of mixed fluid reactions between supercritical carbon dioxide and $\mathrm{NaCl}$ brine: relevance to the integrity of a geologic carbon repository. Chemical Geology, 217, pp. 277-293. http:// dx.doi.org/10.1016/j.chemgeo.2004.12.014

Keeling, C.D. 1960. The concentration and isotopic abundances of carbon dioxide in the atmosphere. Tellus, 12, pp. 200-203. http://dx.doi. org/10.1111/j.2153-3490.1960.tb01300.x

Keighley, D. and St. Peter, C. 2003. Oil, gas, and oil shale resources of southern New Brunswick, eastern Canada. Abstracts, AAPG Annual Conference, Salt Lake City, May 2003, p. A90.

Lavoie, D., Pinet, N., Dietrich, J., Hannigan, P., Castonguay, S., Hamblin, A.P., and Giles, P. 2009. Petroleum resource assessment, Paleozoic successions of the St. Lawrence Platform and Appalachians of eastern Canada. Geological Survey of Canada, Open File 6174, 273 p. http://dx.doi.org/10.4095/248071

Martel, A.T. 1987. Seismic stratigraphy and hydrocarbon potential of the strike-slip Sackville sub-basin, New Brunswick. In Sedimentary basins and basin-forming mechanisms. Edited by C. Beaumont and A.J. Tankard. Canadian Society of Petroleum Geologists, Memoir 12, pp. 319-334. 
Martel, T. and Durling, P. 2001. The petroleum geology of the McCully \#1 gas discovery. Atlantic Geology, 37, p. 119.

Martel, T. and Durling, P. 2004. Update on the McCully gas field, Sussex, New Brunswick. Abstract. Atlantic Geology, 40, p. 149.

Martínez, R., Suárez, I., Zapatero, M.A., Saftic, B., Kolenkovic, I., Car, M., Persoglia, S., and Donda, F. 2009. The EU Geocapacity Project - Saline aquifers storage capacity in Group South countries. Energy Procedia, 1, pp. 2733-2740. http://dx.doi.org/10.1016/j. egypro.2009.02.043

Mito, S., Xue, Z., and Sato, T. 2013. Effect of formation water composition on predicting $\mathrm{CO}_{2}$ behavior; a case study at the Nagaoka post-injection monitoring site. Applied Geochemistry, 30, pp. 33-40. http://dx.doi. org/10.1016/j.apgeochem.2012.08.020

National Oceanic and Atmospheric Administration. 2013. Carbon Dioxide at NOAA's Mauna Loa Observatory reaches new milestone: Tops 400 ppm. URL <http:// research.noaa.gov/News/NewsArchive/LatestNews/ TabId/684/ArtMID/1768/ArticleID/10061/CarbonDioxide-at-NOA A \%E2\%80\%99s-Mauna-LoaObservatory-reaches-new-milestone-Tops-400-ppm. aspx>. October 2014.

Natural Resources of Canada. 2010. Seismic hazard map, Geological Survey of Canada. URL <http://www. earthquakescanada.nrcan.gc.ca/hazard-alea/simphazeng.php >. Accessed October 2014.

Park, A.F. and St. Peter, C.J. 2008. Bedrock geology of the Indian Mountain deformed zone, Westmorland County, New Brunswick. In Current investigations in New Brunswick for 2007. Edited by G. L. Martin, New Brunswick Department of Natural Resources Mineral Resources Report, 2008-1, pp. 78-109.

Park, A.F. and Whitehead, J. 2003. Structural transect through Silurian turbidites of the Fredericton Belt southwest of Fredericton, New Brunswick: the role of the Fredericton Fault in late Iapetus convergence. Atlantic Geology, 39, pp. 227-237. http://dx.doi. org/10.4138/1183

Park, A.F., St. Peter, C.J., and Keighley, D.G. 2007. Structural styles in Late Devonian-Early Carboniferous rocks along the southern margin of the Moncton Subbasin: Caledonia Mountain to Elgin, southeastern New Brunswick. In Geological investigations in New Brunswick for 2006. Edited by G. L. Martin, New Brunswick Department of Natural Resources; Minerals, Policy and Planning Division, Mineral Resource Report 2007-1, pp 87-125.

Perez, R.J., Shevalier, M., Hutcheon, I., and Mayer, B. 2006. A model for partitioning gases among brines and hydrocarbons in oil reservoirs: Examples from the IEA-GHG Weyburn $\mathrm{CO}_{2}$ Monitoring and Storage Project, Saskatchewan, Canada. Journal of Geochemical Exploration, 89, pp. 326-330. http:// dx.doi.org/10.1016/j.gexplo.2005.11.085
Smith, E.A. and Fyffe, L.R. (Compilers) 2006a. Bedrock geology of the Aroostook area (NTS $21 \mathrm{~J} / 13$ ), Victoria County, New Brunswick. New Brunswick Department Natural Resources. Minerals, Policy and Planning Division Plate 2006-14, scale 1:50 000.

Smith, E.A. and Fyffe, L.R. (Compilers) 2006b. Bedrock geology of the Plaster Rock area (NTS 21 J/14), Victoria County, New Brunswick. New Brunswick Department of Natural Resources. Minerals, Policy and Planning Division Plate 2006-15, scale 1:50 000.

Smith, E.A. and Fyffe, L.R. (Compilers) 2006c. Bedrock geology of the Minto area (NTS 21 J/01), York, Sunbury, andQueens counties, New Brunswick. New Brunswick Department of Natural Resources. Minerals, Policy and Planning Division Plate 2006-2, scale 1:50 000.

Solomon, S., Carpenter, M., and Flach, T.A. 2008. Intermediate storage of carbon dioxide in geological formations: A technical perspective. International Journal of Greenhouse Gas Control, 2, pp. 502510. http://dx.doi.org/10.1016/j.ijggc.2008.04.004

Span, R. and Wagner, W. 1996. A new equation of state for carbon dioxide covering the fluid region from the triple-point temperature to $1100 \mathrm{~K}$ at pressures up to $800 \mathrm{MPa}$. Journal of Physical and Chemical Reference Data, 25, pp. 1509-1596. http://dx.doi. org/10.1063/1.555991

St. Peter, C. 2005. Bedrock geology of the Grand Lake area (NTS 21 G/16), Sunbury and Queens counties, New Brunswick. New Brunswick Department of Natural Resources. Minerals, Policy and Planning Division Plate 2005-39, scale 1:50 000.

St. Peter, C. and Johnson, S.C. 2008. Carboniferous geology of the Hillsborough area (NTS $21 \mathrm{H} / 15$ ), Albert and Westmorland counties, New Brunswick. New Brunswick Department of Natural Resources. Minerals, Policy and Planning Division Plate 2008-23, scale 1:50 000 .

St. Peter, C. and Johnson, S.C. 2009. Stratigraphy and structural history of the Late Paleozoic Maritimes Basin in southeastern New Brunswick. New Brunswick Department of Natural Resources, Memoir, 3, 348 p.

St. Peter, C.J. and MacIntosh, J.A. 2005. Maritimes Basin thermal maturation project: Carboniferous organic geochemical (NB_COG) database for New Brunswick. New Brunswick Natural Resources, Minerals Policy and Planning Division, Open File Report OF2005-5, $55 \mathrm{p}$.

Taub, D. 2010. Effects of rising atmospheric concentrations of carbon dioxide on plants. Nature Education Knowledge, 3, p. 21.

Verdon, J.P., Kendall, J-M., White, D.J., and Angus, D.A. 2011. Linking microseismic event observations with geomechanical models to minimise the risks of storing $\mathrm{CO}_{2}$ in geological formations. Earth and Planetary Science Letters, 305, pp. 143-152. http://dx.doi. org/10.1016/j.epsl.2011.02.048 
Wade, J.A., Brown, D.E., Fensome, R.A., and Traverse, A. 1996. The Triassic-Jurassic Fundy Basin, Eastern Canada: regional setting, stratigraphy and hydrocarbon potential. Atlantic Geology, 32, pp. 189 231. http:// dx.doi.org/10.4138/2088

Waldron, J.W.F. and Rygel, M.C. 2005. Role of evaporite withdrawal in the preservation of a unique coalbearing succession: Pennsylvanian Joggins Formation, Nova Scotia. Geology, 33, pp. 337-340. http://dx.doi. org/10.1130/G21302.1

White, C.M., Smith, D.H., Jones, K.L., Goodman, A.L., Jikich, S.A., LaCount, R.B., DuBose, S.B., Ozdemir, E., Morsi, B.I., and Schroeder, K.T. 2005. Sequestration of carbon dioxide in coal with enhanced coalbed methane recovery; a review. Energy and Fuels, 19, pp. 659-724. http://dx.doi.org/10.1021/ef040047w

Wildgust, N., Gilboy, C., and Tontiwachwuthikul, P. 2013. Editorial: Introduction to a decade of research by the IEAGHG Weyburn-Midale $\mathrm{CO}_{2}$ Monitoring and Storage Project. International Journal of Greenhouse Gas Control, 16, Supplement 1, pp. S1-S308. http:// dx.doi.org/10.1016/j.ijggc.2013.03.014
Wilke, F.D.H., Vásquez, M., Wiersberg, T., Naumann, R., and Erzinger, J. 2012. On the interaction of pure and impure supercritical $\mathrm{CO}_{2}$ with rock forming minerals in saline aquifers: An experimental geochemical approach. Applied Geochemistry 27, pp. 1615-1622. http://dx.doi. org/10.1016/j.apgeochem.2012.04.012

Wilson, P. and White, J. 2006. Tectonic evolution of the Moncton Basin, New Brunswick, eastern Canada: new evidence from field and sub-surface data. Bulletin of Canadian Petroleum Geology, 54, pp. 319-336. http:// dx.doi.org/10.2113/gscpgbull.54.4.319

Wilson, R.A. and Ball, F.D. 1983. Carboniferous compilation (2nd Edition) volume II: coal. Department of Natural Resources, Mineral Resources Division, Topical Report 75-20 (Revised 1983), 195 p.

Wilson, R.A. and Kamo, S.L. 2012. The Salinic Orogeny in northern New Brunswick: geochronological constraints and implications for Silurian stratigraphic nomenclature. Canadian Journal of Earth Sciences, 49, pp. 222-238.

Editorial responsibility: Michael B. Parsons 